\title{
CLINICAL OBSERVATIONS ON CHILDREN WITH RETARDED SPEECH
}

\author{
By \\ SHIGeKo MOGI \\ From the Department of Otorhinolaryngology, school of Medicine, \\ University of Tokyo (Director: Prof. I. Kirikae)
}

The problems of children with retarded speech have been noticed by many clinicians such as otologists, speech pathologists, pediatricians, psychiatrists and psychologists.

Present paper is dealing with clinical observations on 466 delayed language cases who visited the hearing and speech clinic for children in E.N.T. Department of Tokyo University Hospital since 1960 to 1962.

Subjects are classified into following groups

1) audimutitas (normal hearing and intelligence)

2) mutism caused by mental retardation (under 84 of $1 Q$ )

3) mutism due to hearing disturbance deaf mutism (threshold is over $61 \mathrm{~dB}$ ) medium deafness $(41 \sim 61 \mathrm{~dB})$ slight deafness $(25 \sim 40 \mathrm{~dB})$

Investigations are made on method of diagnosis, evaluation of speech ability, etiology and treatment.

The informations obtained from parents are found to be unreliable, therefore objective examination is necessary for correct evaluation of speech and hearing ability.

Sixty per cent of the cases are boys and fourty per cent are girls, and most of them (70 per cent) are under 4 years of age.

The further classification and investigation can be performed in accordance with correct evaluation of speech ability.

Poor nurseing environment and brain damages followed by abnormal progress of pregnancy and delivery, especially asphyxia, are considered to be significant as the causes of audimutitas.

On the mentally retarded cases, hereditary pre. dispositions such as mental retardation, neurosis and intermarriage are prominently noted.

Clinically, a group of slight deafness is no1 adequate because 8 per cent of them revealed $a$ profile of the audimutitas and another 26 per cen 1 have mental deficiency. Causes of slight deafnes: is not clear.

Hereditary predispositions (impaired hearing, intermarriage and neurosis), disturbance of pregna. ncy, abnormal delivery, childrens disease with higk fever are considerable factors as the cause of dea mutism and medium deafness.

Patients were treated medically by $\boldsymbol{r}$-aminobu tilic acid and others, and given education by speect therapy. Group therapy for audimutitas childrei is markedly effective and attention to early com mencement of therapy should be paid. 


\title{
言語発達遅滞児の臨床的観察
}

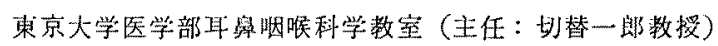

茂梞 しげ子

\section{I.はじめに}

言語機能のむつ意義の電要さが認識されるにしたがつ て，小見に和ける言語の発達やその障害に対する関心 は，多くの専門分野から奇せられている。しかし言語は 人間に扎いて極めて複雑な過程を経て表出されるもので あり，その障害の原因や本態の分折に関しては解明が困 難な多くの問題が含まれている，小児はその成長にした がつて坐活を営むに要する種々の活動機能を備えてゆ く.言語もその機能のひとつで, 步行ととるに人間の発 育段階を知る上において注目すべき事項である。

ある一定の年令に達しながら，言語を理解したり，話 すことができない小照（言語発達遅滿胃）がある。この ような小児をとり技う分野としては小児科，耳鼾科，神 経科，罗童心理，教育関係などがあるが，研究者相互の 意見の交換は少なく，診断や治療に関して多くの問題か゚ 残されている。

小思が言語を獲得するために必要な条件には，身体 的・精神的な成長, 言語に関する諸器官の発達と能力, 適当な刺激と訓練などがある。乙かむこれらの条件は常 に相互の均衜を保つていなけれぱならない，条件の欠如 や不均衡によつて正常な言語発達を遂げられないことが ある.

わが国では言語発達遅㴖といら概念はあまり用いられ ずことばを話さない子供にはそれぞれの分野で適当に ま号まちな診断をつける傾向が強かつた，その結果，ろ う亞や精神薄弱としてとり扱われるものが多くなつてい た、実際には，万う嘼や精神薄弱のいすれれにも属さない、 言語習得障䟧傴が存在する。

このたび著者は，言語発䞗遅滞見について正常な言語 発達と比較しながらその診断の力法, 原因の分析，治療 教育の效果などを检討した。

\section{II. 研究対象およひ研究方法}

\section{1. 研究対象}

昭和 35 年 12 月から 37 年7月市でに東大耳楀咽涙科 小罗難聴言語障害外来を訪机た患者は807 例である、精 密検查により，機能的あるいは器質的構音障害のみと診 断されたもの72 例，聴力障害は認められるが㝘語障富
を伴すない多のが164例あつた。これらの患者と、精密 検査を扣こない得なかつた症例 105 例とを除いた 466 例 について検討をおこなつた。

2. 研究方法

患者の診潦にあたつては，問診，各種の検査，診断と

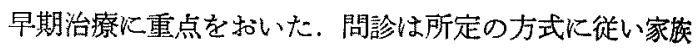
を中心に敊こなつたが，鑑別診断や成因の分類に必要な 資料を得るために充分時閏をかけている，患者心抗むな ら検査としては次のようなものがある.

1. 耳舆咽知科一般検查

2. 聴力检查 簡易方法（話し声，玩具などによる）

精密聴力检査（標潐㯖力検查，遊戯法，脳波火 よる他覚的聴力検查など)

3. 精神発達検查

簡易質問紙（津守氏の変法）による检查 専門医による精神発達検查

4. 害語能力の評価

（言語の理解力, 自発会話の能力, 文章搆造, 語音の明瞭性)

5. 身体発育および健康状態の检査 (小巟科つ協力による)

6. 䛦断的治療

（診断の手がかりをつかをためまたは診断の妥 当性を検討するため)

7. 生育史, 育照環境の分折

检查は患者の年令や能力に応じて選択し，順序も一定 ではない。

\section{III. 研究成績}

研究結果を報告するにあたり，用語の用い万や分類 について检萴する必要があるが考接炕ゆずり，著者は Nadoleczny らの分類を参考沉次のよらな定義の用語と 分類をむらいて報告をすすめる。

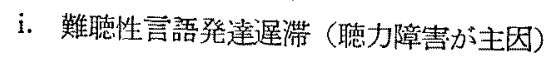

整度難聴（聴力損失 $20 \mathrm{~dB} \sim 40 \mathrm{~dB}$ )

中等度難聴（聴力損失 $40 \mathrm{~dB} \sim 60 \mathrm{~dB}$ )

高度難聴（聴力損失 $60 \mathrm{~dB}$ 以上） 
ii. 精神薄弱性言語発達遅滞（IQ 84 以下のもの）

iii. 聴涇（知能，聴力ともに障害がなく言語機能のみ 遅れているもの. 特発性，心因性のものも含を）

言語理解，自発語ともに不能なもの

自発語のみ不能，もしくは著るしく進くれてい。 るもの

但し, 聴力障害と知能障害が重複しているものは便宜 上難㯖例としてとり扱つた。

1. 年令, 性, 疾患別分布

対象 466 例中，記載が不明なるのを除いた 423 例の性 別比は，男呪刘女児 $3: 2$ で男罗の方が多い，

初診年令では 2 才代が最も多く、3才代がこれにつつ いている（第Ｉ図），疾患別では第】図に示す如く高度 難聴が最も多い，また難聴者は全体の73\%を占的てい る.

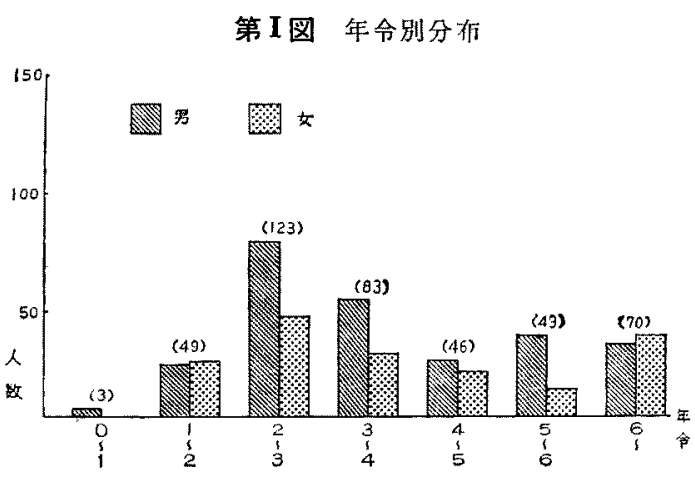

第 II 図 㓋患别分布

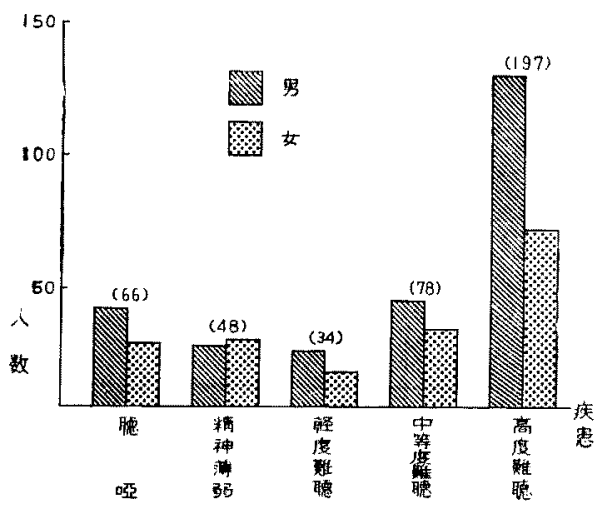

2. 日常生活に打将る音の反応

羙の大きさを大，中，小分けそれぞ机「自動車の警 笛や㱱行機の音に反心するか」、「大声で話しかけたり， ラジオやテレビを大きくしたときに興味を示すか小，「普
通の会話音に反応するか」などの質問を家族に対して未

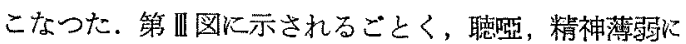
扣いては聴力㭘查により聴覚間值は正常に近いといら程

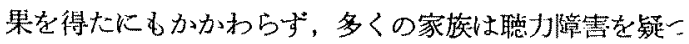
ている $(50 \%)$ ）難聴群について子高度難聴を除いてけ 障害の程度の評価があち亲らである。検查結果と家族 評価が一致しているのは高度難恥群のみであつた。

第 III图 日常音に対する反応

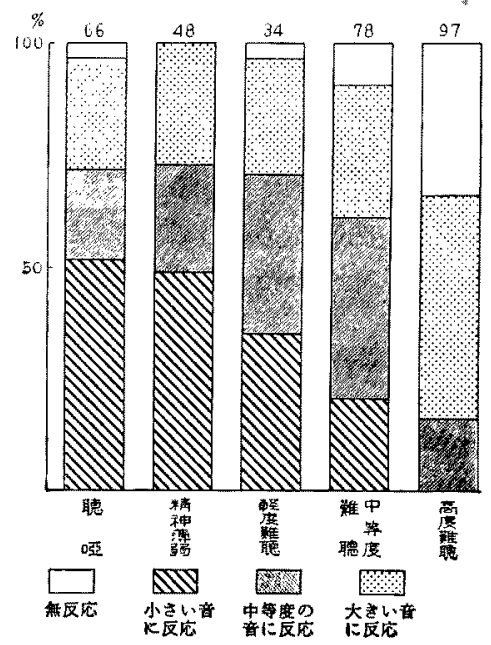

3. 知能による分類

蜼聴と知能障畫を合併している場合は難聴を主にした が，難聴のみで解決できない間題が子想されるので知能 を中心に倹討を加えた。

知能検查は言語障害児の検査に熟練した專門家（神絽 科医）に依頼した。 その方法は1) 田中・Binet 式知能

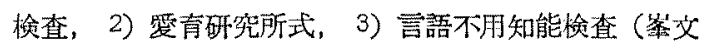
閣), 4) Paper and Pencil B 式, 5) Wisc 法,など を適当に組み合わせたものである。

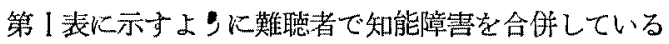
ものは比較的多く，難㯖者の $30 \%$ を占めている．特に

第工表 知能による分類

\begin{tabular}{|c|c|c|c|c|c|c|c|c|c|}
\hline & \multirow{2}{*}{$\frac{\text { 聴 }}{\mathrm{N}}$} & \multirow{2}{*}{$\frac{0}{\%}$} & \multicolumn{2}{|c|}{ 精神辈码 } & \multicolumn{2}{|c|}{ 俥圣度難稣 } & \multicolumn{2}{|c|}{$\begin{array}{l}\text { 中等度 } \\
\text { 難 }\end{array}$} & 高度難聼 \\
\hline & & & & $\%$ & $\mathrm{~N}$ & $\%$ & & $1 \%$ & $\mathrm{~N} \%$ \\
\hline 常 & 66 & 100 & 0 & 0 & 17 & 55 & 37 & 63.8 & $110 \quad 72$ \\
\hline 境界楾群 & 0 & 0 & 3 & 6.3 & 5 & 16.1 & 6 & 10.3 & 128.7 \\
\hline 䊑件海弱 & 0 & 0 & & 93.7 & 9 & 28.9 & & 25.9 & $31 \quad 19.3$ \\
\hline 恰查総数 & & 6 & & 48 & & 31 & & 58 & 153 \\
\hline
\end{tabular}


軽度又は中等度の難聴群では知能発達障畫のあるものが 多小 $(45 \%)$.

4. 罟語発達と身体発育との関係

\section{（1）步行開始の年令}

歩行機能はことぱと同じょらに小児の発育上の一つの 指標であり，運動能力の発達を知る重要な手がかりでも ある。本破究に批いてはひとりで2〜3歩るくことが可 能になつた年命を紧行開始年令とした，盗料は全て問敦 から得たものである。

生後18ケ月までに歩行を開始しなかつたものを步行 迤延とみなす（広島大学团中氏による）上，崌延㑯问が 最も著明なものは知能障害群であつた、難聴群のらち、 難聴が中等度以上のもので歩行開始が遅延したものは約 20\%であり，難德が軽度のものでは4\%となつている。

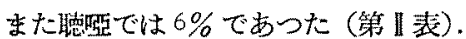

\section{第 II 表 步行開始年 令}

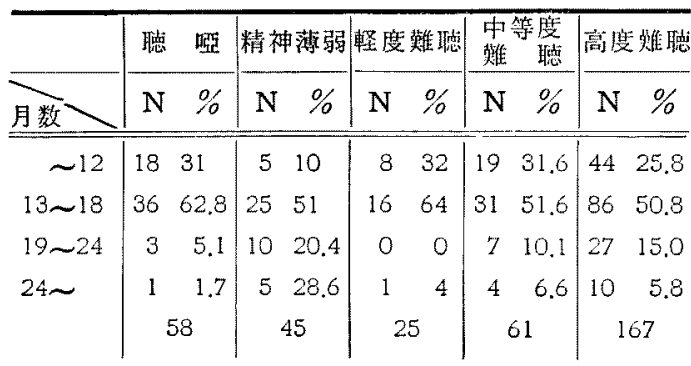

第III表 萠 然年

\begin{tabular}{|c|c|c|c|c|c|}
\hline & & 精神薄弱 & 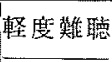 & $\begin{array}{l}\text { 中等度 } \\
\text { 䧼 揌 }\end{array}$ & 高等難聴 \\
\hline 烈数 & $\mathrm{N} \%$ & $\mathrm{~N} \%$ & $\mathrm{~N} \%$ & $\mathrm{~N} \%$ & $\mathrm{~N} \%$ \\
\hline$\sim 6$ & 1126.2 & 410.8 & $6 \quad 35,2$ & 820 & $\begin{array}{ll}31 & 24.4\end{array}$ \\
\hline $7 \sim 8$ & $\begin{array}{l}17 \quad 40.5 \\
(66.7)\end{array}$ & $\begin{array}{c}1951.3 \\
(62.2)\end{array}$ & $\begin{array}{l}5 \quad 29.4 \\
(64.6)\end{array}$ & $\begin{array}{c}19 \quad 47.5 \\
(67.5)\end{array}$ & $\begin{array}{cc}55 & 42,1 \\
(66.5)\end{array}$ \\
\hline $9 \sim 12$ & $16 \quad 33.3$ & 1129.7 & $6 \quad 35.2$ & 922.5 & $31 \quad 24,4$ \\
\hline $12 \sim$ & $0 \quad 0$ & 37.8 & 0 & 410 & $10 \quad 10.5$ \\
\hline
\end{tabular}

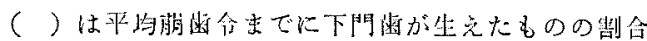

（口）萠歯年令

萠料の年令とことばの関倸は，少行や排便の署慣など 上同じらに一連のものとして考えら机ている。症例の

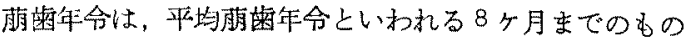
が 65\%であつた。但し 知能障害群ではこれよりやや低 率であつた(第四表)。

\section{5. 初診時の会話能力}

言語の発達段階の評価は理解の能力と実際に話す能力 の雨面から扢こなわなければならないこの検査には適 当な榆査方法と十分な時間，忍酎力などが要求される。 说来はこれらの条件を整えることが困難なために，家族 から会話の椂子を聞き，それを参考にすることが多か た.矢際問題として，外来㟝療で子供に充分な能力を発 揮させるのは困蟇であつた，著者は患者に面接して種々 の会話を試みる他に，家族に質問を出しその解答を参考 にした，家族は多くの場合，子供がことばを理解したの か，垌国の様子や手真似で相手を理解したのか区別でき ない、そのために検者が迷わされることがしばしばあっ た．絬果は第N表に示す通りで放る。

難德が重症である程理解は困難になつている。しか し槙力障害がないか，もしくは軽度であるにも拘わらず 理解不能なものが，聼涇では 12 例 $(17.6 \%)$ ，知能障害 では6 例 (12.3\%) dつた。一方理解可能であつたるの

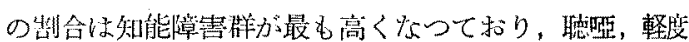
難聴がこれによついている。

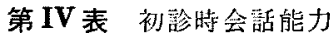

\begin{tabular}{|c|c|c|c|c|c|}
\hline & 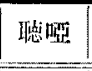 & \begin{tabular}{|l} 
精 神 \\
整 搦 \\
\end{tabular} & $\begin{array}{|ll|}\text { 軽 } & \text { 度 } \\
\text { 䠰 } & \text { 㥁 } \\
\end{array}$ & \begin{tabular}{|l|}
$\mid$ 中等度 \\
雉
\end{tabular} & 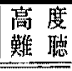 \\
\hline 有意語を持たない & $\begin{array}{c}22 \\
(36.6)\end{array}$ & $\begin{array}{c}14 \\
(35.8)\end{array}$ & $\begin{array}{c}7 \\
(21.9)\end{array}$ & $\begin{array}{c}21 \\
(42)\end{array}$ & $\begin{array}{c}101 \\
(74.7)\end{array}$ \\
\hline 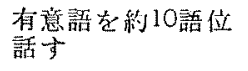 & $\begin{array}{c}23 \\
(38.3)\end{array}$ & $\begin{array}{c}10 \\
(25.6)\end{array}$ & $\left(\begin{array}{c}7 \\
(21.9)\end{array}\right.$ & $\begin{array}{c}4 \\
(8)\end{array}$ & $\begin{array}{r}25 \\
(18.5)\end{array}$ \\
\hline 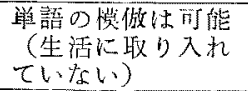 & $\begin{array}{c}15 \\
(25.0)\end{array}$ & $\begin{array}{c}5 \\
(12.8)\end{array}$ & $\left(\begin{array}{c}2 \\
(16.3)\end{array}\right.$ & $\begin{array}{c}4 \\
(8)\end{array}$ & $\begin{array}{c}1 \\
(0.7)\end{array}$ \\
\hline 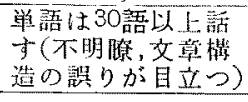 & $\begin{array}{c}1 \\
(1.7)\end{array}$ & $\begin{array}{c}10 \\
(25.6)\end{array}$ & $\begin{array}{c}15 \\
(46.9)\end{array}$ & $\begin{array}{c}20 \\
(40)\end{array}$ & $\begin{array}{c}5 \\
(3.7)\end{array}$ \\
\hline 羟詰の数が減ずる & 0 & 0 & $\begin{array}{c}1 \\
(3.1)\end{array}$ & $\begin{array}{c}1 \\
(2)\end{array}$ & $\begin{array}{c}3 \\
(2.9)\end{array}$ \\
\hline 吕数祽を受けて & $\begin{array}{c}5 \\
(7.5)\end{array}$ & $(11.3)$ & $\begin{array}{c}1 \\
(3.3)\end{array}$ & $\begin{array}{c}2 \\
(3.9)\end{array}$ & $\begin{array}{c}3 \\
(2.2)\end{array}$ \\
\hline
\end{tabular}

第 $\mathbf{V}$ 表 言語理解

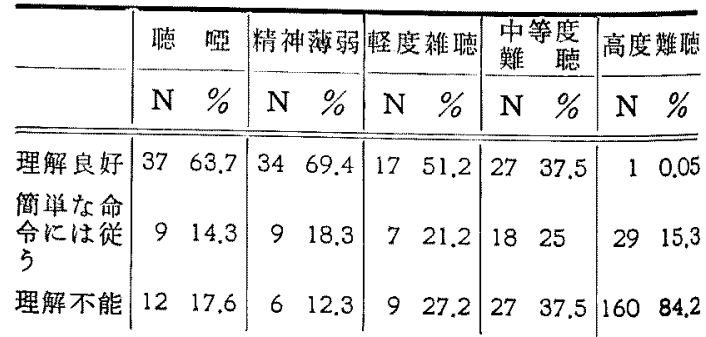


第 VI表 言語理解と自発語数

\begin{tabular}{|c|c|c|c|c|c|c|}
\hline 理解 & 自発誥 & 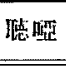 & 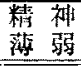 & $\begin{array}{l}\text { 整 度 } \\
\text { 踓 穗 } \\
\end{array}$ & 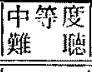 & 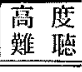 \\
\hline th & 恉 & 18 & 19 & 2 & 0 & 0 \\
\hline 好 & 10玨内外心話す & 19 & 13 & 16 & 24 & 1 \\
\hline 小 & 不 & 7 & 8 & 7 & 6 & 16 \\
\hline 良 & 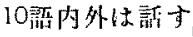 & 2 & 1 & 25 & 8 & 7 \\
\hline
\end{tabular}

理解能力と自発会話能力とは必ずし乎平们しない：こ とばを理解しながら全く会話不能なるのが喯咞では 18 例 (25\%)，知能障害桼では 19 例 $(26 \%)$ あつた。 但し 蜼聴が中等度以上の場合には理解と自発会話はほぼ可行 している.

発音の明瞭性が低い子のは知能障害, 軽, 中等度難聴 者心多く䜑めら机た（第 $N$ ，第V、第V表).

6. 始語年令

意味のあることばを始めて使つた年令壱始語年令とし

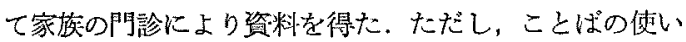
始めを正確に記憶していないものや，ことばの話し始め が遅れているために来院した患者が多く，始語年令を知 り得たわのは一部であつた，初診時に多少とも会話が可 能であり，始語年令をつかみ得たものは第四表に示すと おりである．知能障慧群で，年令が長じて話しはじるる ものが多いのが目立つている。

第 VII 表 始 語 年 命

\begin{tabular}{|c|c|c|c|c|c|c|}
\hline & & 㯖燳 & \begin{tabular}{|ll} 
精 \\
薄 弱 \\
\end{tabular} & \begin{tabular}{ll|} 
㩽 & 度 \\
難 & 聴 \\
\end{tabular} & $\begin{array}{l}\text { 中等度 } \\
\text { 難 梽 } \\
\end{array}$ & \begin{tabular}{|l|l|} 
离度 \\
難 聴 \\
\end{tabular} \\
\hline & $\sim 12$ & $\begin{array}{c}5 \\
(6.4)\end{array}$ & $\begin{array}{c}1 \\
(2,1)\end{array}$ & $\left(\begin{array}{c}4 \\
(11.7)\end{array}\right.$ & $\begin{array}{c}6 \\
(7.8)\end{array}$ & $\begin{array}{c}8 \\
(4,1)\end{array}$ \\
\hline & $\sim 18$ & $\begin{array}{c}12 \\
(18.8)\end{array}$ & $\begin{array}{c}2 \\
(4.2)\end{array}$ & $\left.\begin{array}{c}9 \\
(26.4\end{array}\right)$ & $\mid \begin{array}{c}11 \\
(14.1)\end{array}$ & $\begin{array}{c}21 \\
(10.6)\end{array}$ \\
\hline 19 & $\sim$ & $\begin{array}{c}18 \\
(27.2)\end{array}$ & $\begin{array}{c}22 \\
(45.8)\end{array}$ & $(20,6)$ & $\mid \begin{array}{c}14 \\
(17.9)\end{array}$ & $\begin{array}{c}20 \\
(10.1)\end{array}$ \\
\hline \multicolumn{2}{|c|}{ 有缶語を持たない } & $\begin{array}{c}22 \\
(36.6)\end{array}$ & $\begin{array}{c}14 \\
(35.8)\end{array}$ & $(20.6)$ & $\begin{array}{c}21 \\
(26.9)\end{array}$ & $\begin{array}{l}101 \\
(51)\end{array}$ \\
\hline \multicolumn{2}{|c|}{$\begin{array}{l}\text { 始語の年令を記憶 } \\
\text { していない }\end{array}$} & $\left(\begin{array}{c}9 \\
(11.1)\end{array}\right.$ & $\begin{array}{c}9 \\
(18.7)\end{array}$ & $\begin{array}{c}7 \\
(20.6)\end{array}$ & $\left|\begin{array}{c}26 \\
(33.3)\end{array}\right|$ & $\begin{array}{l}47 \\
(23)\end{array}$ \\
\hline
\end{tabular}

7. 恙語発達遅滞の成因の檢討

(1) 既往歴の検討

言語遅膟の成因に関する定説はないか゚多くの学者の意 見が一致しているのは，子供の生育史（既往摩）上に腷 損賃，新生児・乳児期の直症疾患など遅滞の原因となり 得る事件があるということである，症例の既往歴を中心
に，各群分の原因中原因相互の関係を检討した。原因 便冝上次のよらに分類した。

1) 遗伝性素質が諗められるもの

（Int店結替，類症者，遗伝性疾患など)

2）略型，先天性疾患を合併しているもの （股関笁脱曰，口蓋裂，心臟疾患など）

3) 娃娠十の異管

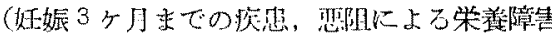
妊强中毒症，出和流座傾问，ホルモン〔黄体

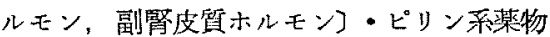

駆虫郕の便用，過学，精神的な負担など)

4) 分婏の翼常

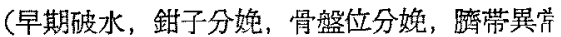

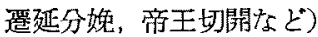

5) 新生児の異常

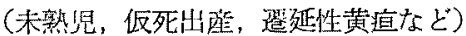

6) 新生思・孚児期の重泟又は慢性疾患

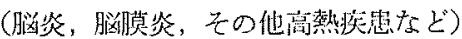

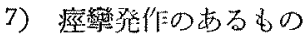

8) ストレプトマイシン，カナマイシンを使用した の

第V表に示すように各群に共通の傾向は，遺伝因子 妊妘目体の罢常，分婏の異常がはぼ同率であること， 児期疾患が多くなつていることである，症例の多くは れらの原因を重複してもつている，その組み合わせと! 因相互の関係については考接で述べる。

第 VII 表 既往歴からみた身体的原因の頻度

\begin{tabular}{|c|c|c|c|c|c|}
\hline 原因 & 聴骝 & $\begin{array}{l}\text { 精 神 } \\
\text { 薄 弱 }\end{array}$ & $\begin{array}{l}\text { 整 度 } \\
\text { 難 聴 }\end{array}$ & $\begin{array}{l}\text { 中年等度 } \\
\text { 嚾 聴 }\end{array}$ & $\begin{array}{ll}\text { 高 } & \text { 豆 } \\
\text { 難 } & \text { I } \\
\end{array}$ \\
\hline $\begin{array}{l}\text { 原因と思われるる } \\
\text { のなし }\end{array}$ & 10 & 4 & 12 & 9 & $1:$ \\
\hline 遣 伝 性 素 質 & 20 & 19 & 3 & 22 & $6 \mathrm{e}$ \\
\hline 畸型，先天性疾患 & 1 & 7 & 0 & 6 & $\varepsilon$ \\
\hline 弤赈経過の㗨常 & 20 & 14 & 4 & 22 & $6:$ \\
\hline 分娩の異常 & 18 & 14 & 1 & 8 & $4 i$ \\
\hline 未熟児 & 12 & 19 & 0 & 9 & $4:$ \\
\hline 仮 死 & 10 & 8 & 2 & 6 & 31 \\
\hline 翼常 & 3 & 4 & 0 & 2 & 4 \\
\hline 乳児期疾虫 & 24 & 20 & 11 & 25 & $10:$ \\
\hline 痤䅐を合作 & 9 & 13 & 3 & 10 & 16 \\
\hline $\begin{array}{l}\text { ストレプトマイシ } \\
\text { ンの使用 }\end{array}$ & 4 & 4 & 0 & 12 & 4 \\
\hline
\end{tabular}


第 IX表 出生順 位

\begin{tabular}{|c|c|c|c|c|c|}
\hline & 踾 啡 & 精神荆弱 & 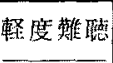 & $\begin{array}{l}\text { 中等度 } \\
\text { 嚾 } \\
\end{array}$ & 高笭矔德 \\
\hline 順 位 & $\mathrm{N} \quad \%$ & $\mathrm{~N} \quad \%$ & $(\%)$ & $\mathrm{N} \quad \%$ & $\mathrm{~N} \quad \%$ \\
\hline 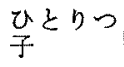 & $6(11.6)$ & $15(28,8)$ & 0 & $5(9.6)$ & $75(43,3)$ \\
\hline 長 & $12(23.5)$ & $8(15)$ & $5 \quad(50)$ & $20(38.4)$ & $28(16$ \\
\hline 末 & $29(56.6)$ & $23(43.3)$ & $5 \quad(50)$ & $20(38.4)$ & $57(33)$ \\
\hline その他 & $4(8.0)$ & $6(11,3)$ & 0 & $7(13.8)$ & $13(7.5)$ \\
\hline
\end{tabular}

第 $\mathbf{X}$ 表 a 親の年命（分娺時）

\begin{tabular}{|c|c|c|c|c|c|}
\hline 年命 & 衈 骂 & 精神海㿟 & 经度斡俧 & $\begin{array}{l}\text { 中等度 } \\
\text { 難 聴 } \\
\end{array}$ & 高度嚾聴 \\
\hline$\sim 20$ & 0 & 0 & 0 & 0 & $\left(\begin{array}{c}2 \\
1.1\end{array}\right)$ \\
\hline $20 \sim 24$ & $\begin{array}{c}15 \\
(30)\end{array}$ & $\begin{array}{c}12 \\
(25.5)\end{array}$ & $(29.1)$ & $\left(\begin{array}{l}14 \\
23\end{array}\right)$ & $\begin{array}{c}51 \\
(27.8)\end{array}$ \\
\hline $25 \sim 29$ & $\begin{array}{c}16 \\
(32)\end{array}$ & $\begin{array}{c}17 \\
(35.7)\end{array}$ & $\begin{array}{c}11 \\
(45.8)\end{array}$ & $\begin{array}{c}30 \\
(49.1)\end{array}$ & $\begin{array}{c}78 \\
(42.6)\end{array}$ \\
\hline $30 \sim 34$ & $\begin{array}{c}16 \\
(32)\end{array}$ & $\begin{array}{c}6 \\
(12.7)\end{array}$ & $\begin{array}{c}5 \\
(20.8)\end{array}$ & $\begin{array}{c}12 \\
(19.6)\end{array}$ & $\begin{array}{c}37 \\
(20.2)\end{array}$ \\
\hline $35 \sim 39$ & $\begin{array}{l}3 \\
(6)\end{array}$ & $\begin{array}{c}5 \\
(10.6)\end{array}$ & $\begin{array}{c}3 \\
(11.6)\end{array}$ & $\begin{array}{c}3 \\
(4.9)\end{array}$ & $\begin{array}{c}8 \\
(4.4)\end{array}$ \\
\hline $40 \sim$ & 0 & $\left(\begin{array}{c}2 \\
4,3)\end{array}\right.$ & 0 & $\begin{array}{c}2 \\
(3.5)\end{array}$ & $\left(\begin{array}{c}7 \\
(3.8)\end{array}\right.$ \\
\hline
\end{tabular}

第 $\mathbf{X}$ 表 b 父親の年令 (患者出生時)

\begin{tabular}{|c|c|c|c|c|c|}
\hline 年命 & 聴 咥 & 精神薄弱 & 怪塺難衈 & $\begin{array}{l}\text { 中等度 } \\
\text { 䧼 槙 } \\
\end{array}$ & 高度知僬漗 \\
\hline $20 才 \sim 24$ & $\begin{array}{l}2 \\
4\end{array}$ & $\left(\begin{array}{c}1 \\
2.1\end{array}\right)$ & $\left(\begin{array}{c}1 \\
3.8\end{array}\right)$ & $\left(\begin{array}{c}4 \\
6.5\end{array}\right)$ & $\begin{array}{c}8 \\
(4.5)\end{array}$ \\
\hline $25 \sim 29$ & $\begin{array}{c}16 \\
(32)\end{array}$ & $\begin{array}{c}12 \\
(25.3)\end{array}$ & $\left(23^{6}\right)$ & $\begin{array}{c}22 \\
(36.6)\end{array}$ & $\begin{array}{c}54 \\
(30.6)\end{array}$ \\
\hline $30 \sim 34$ & $\begin{array}{c}18 \\
(36)\end{array}$ & $\begin{array}{c}20 \\
(42.5)\end{array}$ & $\begin{array}{r}14 \\
(53,8)\end{array}$ & $\begin{array}{c}23 \\
(37.7)\end{array}$ & $\begin{array}{c}74 \\
(41,8)\end{array}$ \\
\hline $35 \sim 39$ & $\begin{array}{c}10 \\
(20)\end{array}$ & $\begin{array}{c}4 \\
(8.5) \\
\end{array}$ & $\begin{array}{c}4 \\
(15.3)\end{array}$ & $\begin{array}{c}10 \\
(16.3)\end{array}$ & $\begin{array}{c}33 \\
(18.7)\end{array}$ \\
\hline $40 \sim 44$ & $\begin{array}{c}4 \\
(8)\end{array}$ & $\begin{array}{c}3 \\
(6.4)\end{array}$ & $\left(\begin{array}{c}1 \\
3.8\end{array}\right)$ & $\left(\begin{array}{c}1 \\
1.6\end{array}\right)$ & $\left.\begin{array}{c}7 \\
(3.9\end{array}\right)$ \\
\hline 45 & 0 & $\begin{array}{c}7 \\
(14.9)\end{array}$ & & $\left(\begin{array}{c}1 \\
1.6\end{array}\right)$ & $\left(\begin{array}{c}1 \\
0.5\end{array}\right)$ \\
\hline
\end{tabular}

（口）同胞数と出生順位

言語発達遅滞児ではその兄第の数や出生順位か゚ことば の発達に影響を及注す要因々考劣られている。第风表に 示すのは症例の出生順位である，㦈力障害がかかもし

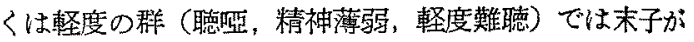
多くなつているが，高度難聴ではひとりつ子の割合が多 い，各群の共通点は出生順位が中間である症例が少ない ことである。

\section{(八) 父传の年令}

症例出生時の兩親の年令加らある程度，その家族の社

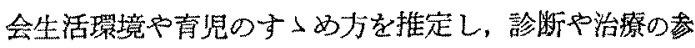
考比するこができると教，父母の年令を第 X表（a b)に屯とめた。

8. 治療とその緋過について

全症例 466 例のうら経過を追うことがでさたのは 235 例である、観察期間の最も長いるのは1年9カ月で, 短 かいるのは 2 カ月である. 症候別に芫ると聴硜の観察が 最も長く症例の数も多い $(90 \%)$.

治療の力針は，知能に障害がなく聴力障書もないかま たは軽度である場合には，家庭指導や個人指道まなは普 通幼稚園に通園させるなど自然の状態で訓練した。難聴 が中等度以上の場合は一応るう教育の対象としたが，家 族の熱意が強く教育し得る素質があると思われる場合 は，中等度の症例です家庭教育及び個人指導に重点をお いた，家庭教育及び個人指導の内容は别報に执いて詳迹 する予定であるが1日30分名ら1時間，日常生活に必 要なるのや絵本を中心教育する方針をとつた。

第り表には，治療教育の遂行が確認されたものが示さ れている。ここで注目されるのは腮力障書がないにか かからず，ろら教育を受けているものが12 例（聴䧈? 例，知能障害 5 例 あつたことである。これらはすべて

第 XI 表 その後の治瞭教育

\begin{tabular}{|c|c|c|c|c|c|}
\hline & 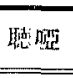 & 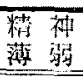 & 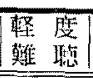 & 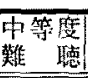 & 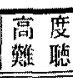 \\
\hline 临 通 教 育 & 0 & 0 & 0 & 0 & 0 \\
\hline 堷通幼稚園 & 12 & 6 & 10 & 11 & 0 \\
\hline 疑 䍡 学 粐 & 0 & 0 & 3 & 2 & 0 \\
\hline 万稚部) & 7 & 5 & 2 & 12 & 45 \\
\hline 万う唖学校教育相 & 0 & 0 & 6 & 0 & 26 \\
\hline 特殊学級・地 滾 & 1 & 1 & 2 & 1 & 1 \\
\hline 個 人 指 導 & 10 & 0 & 10 & 1 & 0 \\
\hline 家 庭＼cjkstart訓 & 39 & 4 & 4 & 19 & 10 \\
\hline
\end{tabular}


患者の家族の程極的な意志でるら教有を選んだものであ る.

\section{IV. 総括と考按}

〈用語と分類について〉

小児の発育にともないある適当な時期に学習されるべ き言語が学習されず発達遅滞をきたした場合，その遅れ ている状態を簡漝にしかる適確に説明する用語が必要で ある。また発達障害の程度や原因によつて分類すること も必要である，言語発達遅滞の堦合にはこの分類が診断 や治療の第一歩となり得る。

Stinchfield（1928）の報告によると言語の遅れている 。のや，全く言語を発しない状態を表現する用語には次 のようなむのがある.

alalia (発語不能症)

alalia cophotica: deaf mutism K相当

alalia organica：構音器官の異常による発語不能症 alalia physiologica：生理的発語不能症

alalia prolongata: 嗹延性発語不能症

aphemia（運動性失語注）

dumbness (啞)

lingnal arrest of development（言語発達遅滞）

deaf mutism (ろう啞)

hearing mutism (聴哑)

hysterical mutism (ヒステリー性噚)

lalophoba (発語恐怖症)

phonophoba（音声恐怖症）

などである。このらち比較的よく用いられているのは "alalia"と "deaf mutism”であるが, alalia は Hordt が「言語による表現能力の障害」といら意味で用いたる のであり，構音器官の異常などによる構音障害も含まれ

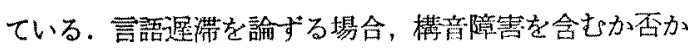
が常に問題になる，著者は言語発達遅郚を感覚渦程（理

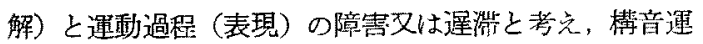
勘のみの障害は除外した。したがつて alalia た朋いる ことは不適当である。

聴力障害が主な 原因である場合には deaf mutism,

Taubstummheit が多く用いられている，知能障害（精 神薄弱)に上る暨には mutism due to mental retardation, Mutitas idiotica などが用いられ用語の混乱は 比較的少ない。

用語の用い万が最も複䧴なのは，聴力や知能に障害が なく言語機能のみに遅れのあるるのを表現する場合であ る.醇語を話さない状態が aphasia (失語怔) に類似し ている(一部の学者は失語症と同様の脸障害を主張して
いる) ところから congenital aphasia (先天的失語将 Cotard, McCall, Morgan など) もしくは aphasia chidren (小巟失語症-Karlin, Simonson など) が用 られている。これらは主としてアメリカ学派の報告に くみら机る、一方ドイッ学派の考光方にもとつくもの は audimutitas, Hörstummheit (聴力障㕩, 知能障 がないにもかかわらず言語を話さない、唤-Coen）が る。これ忙 aphasia（失語症）上り症候を忠実に表現 ている。この他化 Speech inhibited child (言語発鼓 物児-Chopin) p idiopathic language retardation ( 発性言語遅滞-Nance）などがある。

以上のよらに用語に関する諭義は複雑で，しかる16 年代の半頃から今日までつづけられている，Blau ら 述べているように，これらの用語を統一することは困 であろう。したがつて本研究の報告に際しては便利て 乱の少ない用語を朋いるようにし，充分説明を加える うに努めた。

分類についても Nadoleczny らを中心にするドイッ 源の考光方と Karlin らを中心とするてィリカ学派の え方がある、前者はVerzögerte Sprachentwicklung( 語発達遅滞) Taubstummheit(万弓洍)，Hörstum

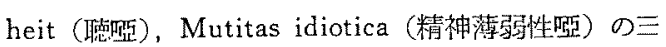
に分類している，後者は delayed language develop entを成因に重点を批いた分類，すなわち1）due hearing disturbance (㯖力障害に上るもの)，2） d to mental retardation (知能障㫪に上るもの)，3） d to another causes (その他の原因によるるので audin titas, psychological disturbance などを含む) を斥 ている.

わが国のむのでは馬場の分類がある。これは前に迅 た二つの学派の分類より成因の区分がこまかく，が 体的である.すなわち

1. 身体発育不全性雲語幄㴖

(delayed speech due to general developm tal retardation)

2. 心因性言語遅刻

(delayed speech due to psychic or envir mental factors)

3. 難德性言語掘㣴

(deaf mutism)

4. 精神薄强性言語崌膟

(delayed speech due to mental retardatic

5. 脸性麻痻性言語遅滯 
(cerebral palsy speech)

6. 特発性言語逮滞

(idiopathic language retardation)

である、本来，分類以疾病の治療や子後の判定に有力な 签料を得るために抗こならものである，したがらてこの

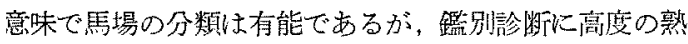
揀と経猥を要し，また複猚な患者ではいくつかの分類に またがる場合も考光られるので䦌題がある。

著者は先き述ベた三つの倾向の命類る考慮し, 次の 分颣を用いた。

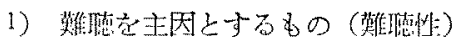

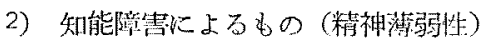

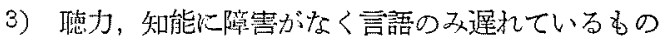
(读哑)

〈底例の检討〉

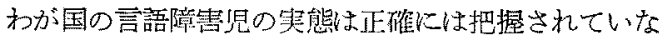
、その原因は，言語障害を專門的に診断したり治療す

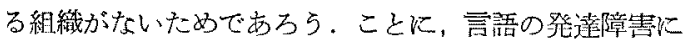
明しては参教にし得る統計や資料索見出すことができな

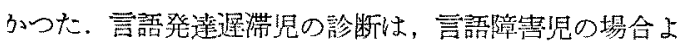
りはるかル国難である、言語遅湍わ言語障害の一部分で 方り今後の研究にまつところが大きい。

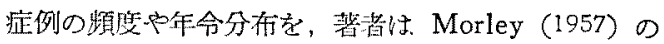
段告上比較した。

\section{茂 木}

性地

\section{男児対女星}

$256: 167$

$(3: 2)$

最頻年令 2 年1 为月〜 3 年闹力月

症侯别

\begin{tabular}{|c|c|c|}
\hline & 茂 木 & Morley \\
\hline 難 㯖 & $67.2 \%$ & $43.5 \%$ \\
\hline 和能陪慧 & $15.8 \%$ & $27.3 \%$ \\
\hline 两焉 & $17.0 \%$ & $29.2 \%$ \\
\hline
\end{tabular}

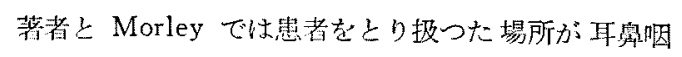

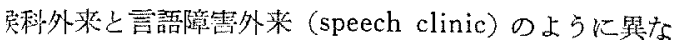
つているので各群の占める割会には差があるが，難德が

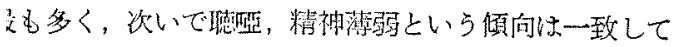
万.

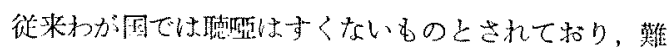

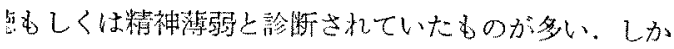

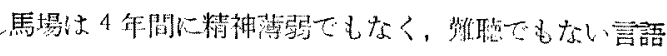

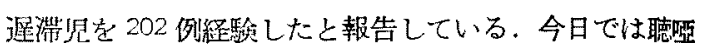

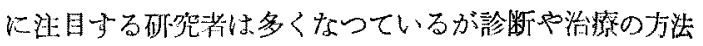
証磪立されていない。

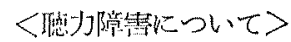

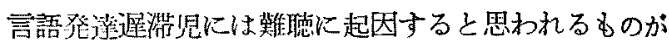

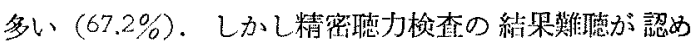

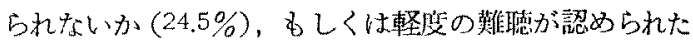
もの $(8 \%)$ でもこのらち約 50\% は家犊に上つて難隠の

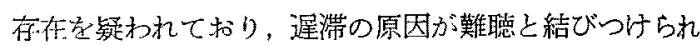

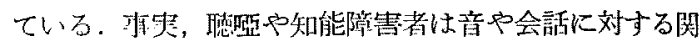

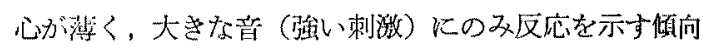
があり、難聴との鑑別打困難であることが多い：しかし 注意潹い観察や精密㯖力検查などにより䨅聴は除外する ことができる，検查の力向の決定や診断に際して，家族 の挀之や钼察は参考にし得る盗料ではあるが，全てを信 じるには危険か件う。

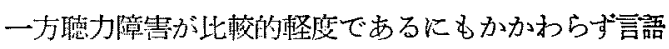
機能が藷しく低いるのがある。これらについては㯖力以

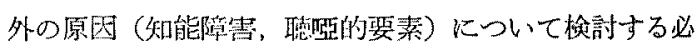
要がある。すでに述べた如く，軽度乃至は中等度難聴で 知能に障害をもつものが 45\%みとめられている.

〈知能発洼障蜔について〉

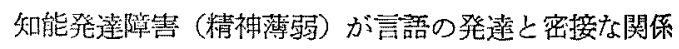
にあることには多くの学者の意見が一致している．Nadoleczny 5 も精神年令と需語能力は平行すると述へて いる，知能指数上言語発達の直接の閔俰は未だ解明され ていないが，知能指数が低いほど始語の年令が大きくな ることは Gesell, Morley, 小野らによつて 報告されて いる，著者の症列であ同し傾向がみ゙られた。

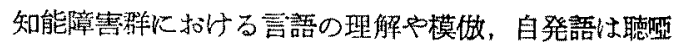

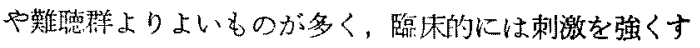
る（大声で話しかける）とことばに反応しやすくなるこ

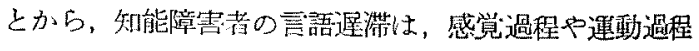

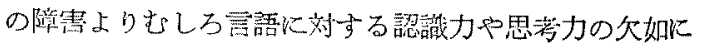
もとつく西のと思狆る。

<言語発澾と身体発育上の関係〉

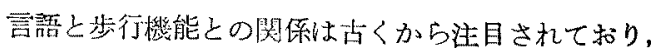

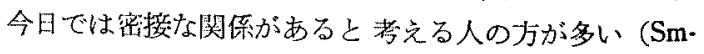

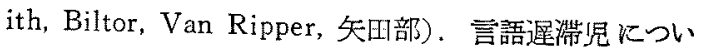

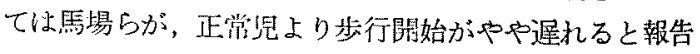
している，著者の淤例では12 カ月をでに步行を開始し たもの恬正常胃が $63 \%$ であるのに比し約 $38 \%$ で低率て あるが，18カ月本でに80\%以上のものが韭るきはじめ 
ている.しかし症候別にみると知能障害㫛では 18 カ月 までに歩行を開始したるのは50\%にすぎない，これは 精神薄弱の特改でもあり言語遅延と特に関係が深い、歩行 荤延とは考完られない，全例を通してて，歩行の開始は正 常児よりやや遅れる傾向があるという結論㑢した。

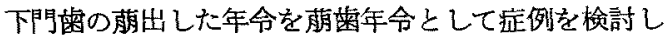
た。最頻年令といわれる生後 8 力月むで第一宩が萠出 したものは65\%であつた，ただし残りのものでは多く が 12 力月以内に萠出している。したがつて 畨の萠出年 令関しても著るしい幄れや，特有の䫝向は認められな かつた。

身体機能と言語遜滞の関係について Beckey (1946) らは，障害児の身体条件や青罗条件は正常罗に比して琴 いものが多いと述べているが，㸃例では步行開始や萠菌 などの身体発育については㥩るしく不利な条件は見出せ なからた。

〈始語年令と会話能力〉

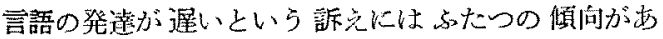
る、ひとつはことばの始まりが掘いというものであり， もら一つは年令比比較して会話能力が低いといらあので ある、家族がこれらの疑いを持ち始めるのは 2 才から

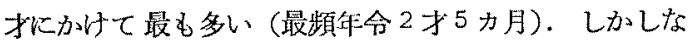
がら言語発達の明確な基準は作られていない，そこで著 者は，すでに報告した如く，正常幼雅園児の言語発達を 調查し，その結果を基準に言語遅滞児を検討した。

症例の始語年命で特徽を示しているのは知能障害蓷で ある.この群で捗行の遅延傾向と同しく始語も著るし

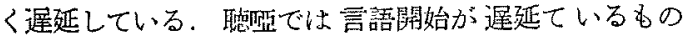
と，言語の開始注平均年令 (11 力月～1年 6 力月）以内

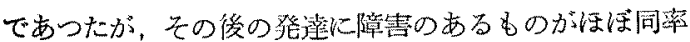

第IV 图 始語年命百分比

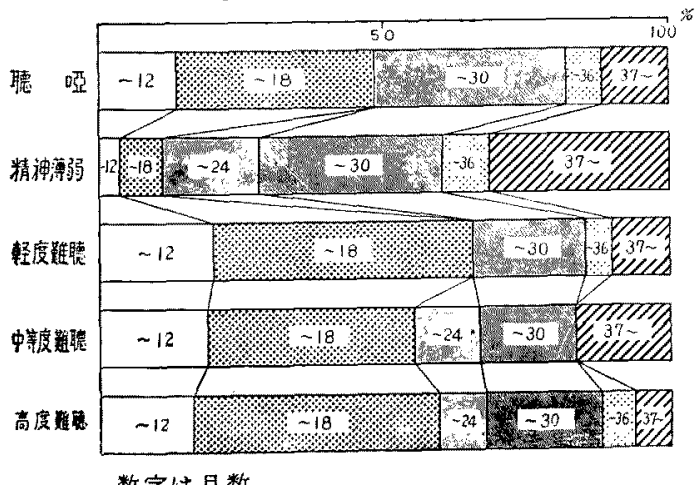

数字は月数
であつた，知能障害児では，年令が長じ身心の機能力 達するとことばを話し始めるが，恥䀦の場合は身心。 能に著るしい遅れもなく，時間が経過しても言語開妒 みないことから，身心の成熟や年令（時問の経過）。 で解決できない問題を含んでいると考えられる。

㯖力障害が活とんど認められないか，あつても極女 軽塨であるにもかかわらず言語を理解しない症例，寸

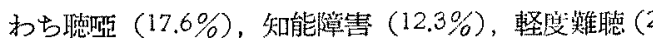
\%)などがあつた，聴涇の場合，この上うな状態にす むのを McCall (1911) は“語らう” (word deafne と名ら゙けており，Worster, D. \& Allen (1929) は先 性言語理解不能症 (congenital auditory imperceptic であると逝べている。また著者らが用いている挖咡す

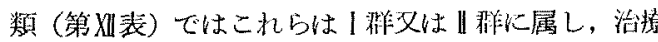
育により III群からリ群へ進み，正常発青に近づく。 思われる。

第 XII 表 呫嵒の分類

\begin{tabular}{|c|c|c|c|c|}
\hline 刺 㠜 & \multicolumn{2}{|c|}{ 音 } & 瞢 & 嚾 \\
\hline 分類 & $\mathrm{E} \cdot \mathrm{E} \cdot \mathrm{G}$ & 行 跑 & 理 解 & 会 話 \\
\hline I 橏 & $t$ & - & - & - \\
\hline \| 潇 & + & + & - & - \\
\hline III 猜 & + & + & $t$ & - \\
\hline N 羣 & + & + & $t$ & + \\
\hline
\end{tabular}

知能障害者で言語を理解しないものの多くは知能発 が著るしく掘滞して特り，言語以外の発青障害を合併 ているものが多く譛められた，如能障害者では精神機 が未発達なため語を理解与る能力が欠如していると えられる。

軽度難鱾者で言語理解不能なものを検討小ると，聴 に近い条件至持つものと，知能障害があり精神薄弱に いと思尒れるものとがあった。つまり9例の5ち，7

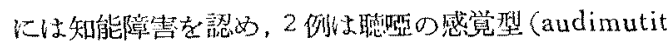
の sensory type 訧 congenital auditory imperce tion）に近いものと思われた。

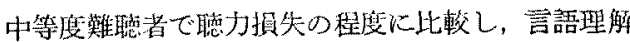
瑟いもの (27 例) がありこれらについても約半数に 知能障害がとめられた。しかし難㯖者で，聴力障害

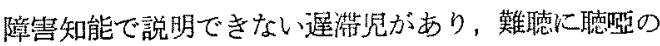
素を合わせるつていると思われる症例がみとめられた は注目すべきである。

一方，言語理解が可能な難范者について検討すると 
後天性の難衈で発病後6カ月以内のものが多かつた，中 等度難聴者では言語理解上聴力型は関倸があり，高音部 急墜型のものに些解がよいものが多かつた，ただし，る ら教育を受けているもの除外した。

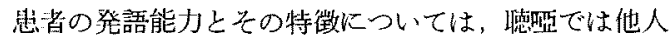
の言語は十分理解可能であるが一語も話さないものと， 自発語は10語位可能であり求められれれば答えるといら るのがあつた，その比率は後者の方がやや多い，また原 因などの分析は後者の方が容易であり，治㞠も効果的で 如つた，前者に执いては治療程過中発音に企を生じるも のが多く，長い治療期間学要した，知能障害者の会話の 特徽は，相手を理解しながら全く会話は不能であるも の，ことばの数や質上りも発音の歪や不正確さが目立つ もの（例壳ばキヤラィルがある時はヒヤマレルになり， ある時にはサマレルになり，またキャラィルと正しく発 湆することいある)，文章をつつうつて話しをすることが できないものの三つであつた。またこれらの知能障害者 では言語の模做が容易であることや語音の刺激を強くす ると、ことばは明瞭になるといら他の群に見られない特 徽がみとめられた。

\section{<原因の考察〉}

原因を論じた文献は多い(Beckey 1946, Goldstein 1958, Peacher 1949 など)が，それぞれ研究者独自の 意見であり決定的なるのはすくない，本症例の場合る因 果関保を断定する資料を得ることはできなかつたが，原 因として考学得るものについて検愊を行つた．原因のら ら比較的頻度が高いのは妊娠分婏時の 異常と乳児期疾 患（高熱，慢性疾患など）である。この傾问は軽度難聴 (すでに述べた如くこの群のもので塄䀦や知能障害の条 件を持つものはをれぞれ該当する群に加えた）を除いて は共通している。

原因項目の分類には Beckey や Goldstein の報告を 参考にしたが，この原因が単独で認められたものは少な く，多くのものは2つ以上の原因を重複して持つてい た。患者 1 人当りの平均負荷数は聴噚 $(1.89)$, 知能障 青 (2.0), 俥度難聴 (2.3), 高度難聴 (2.2) であつた。 3eckeyはこれらの原因について正常胃に起つた頻度と 言語掘滞胃の場合を比較しているが著者は二つ以上の原 因をるつものの組み合わせについて検討した。

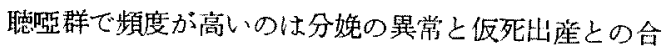
并であつた. Beckey や馬場らも分娩周辺期の異常は子 共の脑障害を掓こしやすく言語嬳得障害の原因となり得 らと述へているが，本拉例では特江翼常分娩之仮死出虐
との強い結びっきが認められ，馬場らのいう脳傷害も一 因ではないかと考えられた。

知能障害群では遣伝性疾患の素質が注目された，特て 精神薄弱の類症が多くみられたが，これと痤檠を伴う乳 児期の疾患が合併しているものが此較的多かつた．これ らは知能障害をきたしやすい原因ではあるが，言語発達 遅滞之直接の関係はないよらに思われた。

軽度難聴者（聴鸪に近いもの，知能障管のあるものを 除いた）では症例数が少ないために一定の傾向をつかむ ことが困難であつた。

中等度，高度難㙏で过遗伝素質と乳巟疾患の合併，遺 伝素質上妊娠母体の異常が合侀しているものの頻度が高 からたが一方遗伝素質とは無関保に妊娠や分婏の異常と 乳罗期疾患を合併したものも多く認められた，遺伝素質 に含まれているものには難聴の類症者と畸型がある，以 上のことから妙巟が素質としてもつている異常性（難嵒 を标こしやすい素質）にそれを誘発する力（娃娠，分娭 の異常，乳巟疾患など）が働いた場合に難㯖が就こると いうことが考克られる。 また妊娠初期の異常が聴力障害 を怙こしやすい状態（素質）を作ることも考えられる. 高度難聴の原因で特敏的なものにストレプトマイシンの 注射がある。これらの多くは急性熱性疾患もしくは慢性 疾患に用いられたものであるが，脳炎・髓膜炎のよ5に 知患自体が内耳聴神経を侵すものもあり必ずしもス卜 レプトマインンによる難聴とは断定できないものもあっ た。しかし，症例のなかには小胃結核や慢性筲炎，気管 支炎でストレプトマイシンによる治療を受けたものる多 く、またこれらの患者に打いて他に原因と思われるすの を持たない例が多いことからストレプトマイシンによる 聴力障害と考皇たものも少くない，ただし使用量との関 釈圢不明である。

<同胞数と出生順位 $>$

青見の環境が言語の発達におよ括す影響は大きいと考 えられている. Smith や Davis は言語遅滞児 (聴置) にはひとりつ子より兄弟のある子供が多いと報告してい る. 一方 Irwin らの報告では言語発達と同胞数とは算 関係であるという，本症例でも同胞数に関してはなんら 特票的な傾向をつか及得なかつた。ただし出生の順位に ついて中間のものが少く，第1 子又は末子が多い傾问

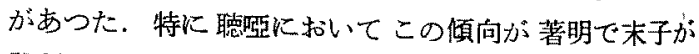
$57 \%$ を占めている，この現象の解釉には困難が予想され るが，母親や家族の育児態度が問題になつてくる、つま り患畒以外に子供充てた経験があるために，すへてを 
他の子供に準じて処偶する．その結果子供が言語に対す る與味や必要性を感じないまをに成長し，ひいては言語 発達遅滞をきたすことも考えられる. Irwin も母親の育 児能力に原因があることを指摘している．

〈父母の年令 $>$

前項でもられたが外国の報告には育児の問題が大きく とり上げられている. 特に父母の年令や教育程度を指標 にしているすのが多い，症例では職業や学歴について詳 細な資料を集めることができなかつたので年令について 考察をす寸める．母親の年令ではいずれの群に拈いても 25 才 29 才が多い，これはこの年令での出産人口が最 も多いことから当然起つてくる現象と考兄られ, 言語遅 滞に特有な傾向ではない，昭和 34 年度の 産掃年令を対 称として本症例に打ける母親の年令を比較すると（第 V 図)，聴涇群飞おいて一般の傾向上り若い年令のものと， より年をとつた年令 (20 才〜24 才，30才〜34 才）のも のが多くなつていることが注目される. 母親の年令恃し ばしば妊娠や分婏の能力と直接結びつけて考号られるこ とが多い，特に聴涇では分婏異常や仮死出生の既往歴を 持つものが多いことから奸娠分婏能力と母親の年令との 関釈は注意寸べきである，乙かし㯖硜症例において分婏 異常と年令分布をみると，年令が長じるほど分婏異常は 多くなる傾向はみとめられたが著るしい片寄りは認めら れなかつた．むしろ若い年令の母親で分婏異常もなく言

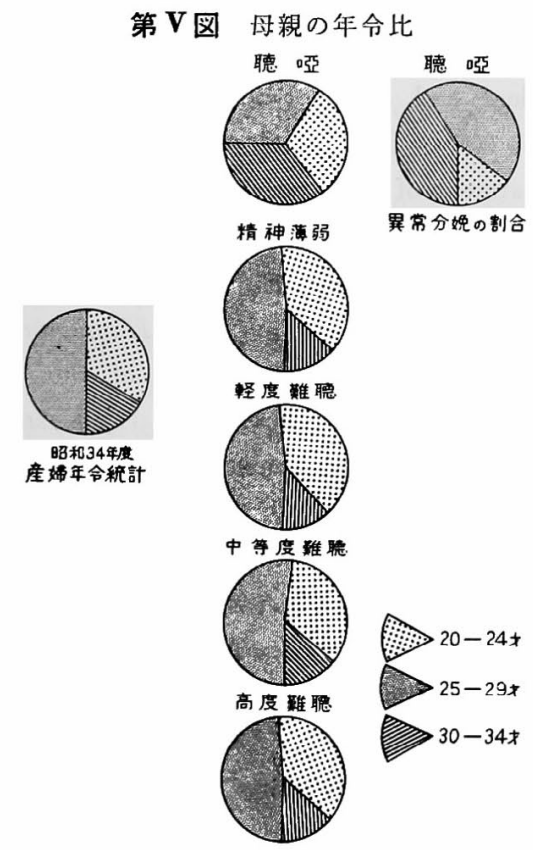

語遅滞を訴えるものが多いことに注目したい(第り図). したがつて聴恶では育見の能力の問題が 表面化してく る.

広島大学の田中の報告によると単純性言語遅漁（聴䙵 に相当する）では若年令の母親が多く，これは有児の能 力（育児環境，方法など）に問題があると述べている. 本症例でも若い母親で育児能力の未熟さが問題視された ものは多い，この場合多くはひとりつ子または長子であ つた．一方 30 才以上の母親に执いても不適当な育児に 原因があると思われるものがあり，いづれも数人の子供 を育てた経験のある母親であつた．子供を育てたことが あるといら経験から他の兄弟に準じて子供をとり扱うと ころに問題があると考兄れる.

父の年令でも 25 才 30 才が多いのは，母親の場合と 同じでこの年令が一般的最頻年令である. 精神発達障害 者群については父母の年令はともに大きい方に片寄る傾 向がある.これは知能障害者が生れやすい原因の一つで はあるが言語遅滞との関係は二次的なるのであろう.

〈環境因子について >

言語発達と 環境からの 刺㦸は切り離すことができな い症例で，明らかに言語環境が不良であると思われる ものに次のものがある．1）雨親とも職業人である．2) 大人の家族が多い，3）身体の弱、子供を保護しすぎる. 4）両親以外の人に育児されている（老人，施設など） 場合、このような環境のもとにおいては, 多くの場合, 子供は言語への関心とその必要性を感じないそそのため に，身心の発育に比して言語のみが遅れて行くといら絬 果になる.

<治療〉

早期発見，早期治療教育は治療の必要条件であるが実 行には困難が伴うすでに述べた通り症例は 3 才以下の ものが多く，このよらな小児に治療や教育を施こすの は，言語障害つ治療体系が整つていないわが国では殆ん ぞ不可能に近い，難聴や精神薄弱者についても患者が正 式な教育を受けられるのは6才以降である（多少例外は ある).この状態では早期診断も意味がなく, 言語発達 の盛んな時期を見送つてしまら結果になる，最近では早 期治療の要請が強く， 万う児の教育に関しては $3 \sim 4$ 才 児を対象にする学校も增えてきた，ただし，聴涇や言語 遅滞のある精神薄弱者についての見透しは暗い，著者は 全ての症例に，診断の決定とともに家庭教育を指導し た. 難聴児(聴哑，精神薄弱のため言語を理解しないもの もこれに準ずる）には補聴器などによる音感訓練を，そ 
つ他の場合には言語訓練を抗こなつた，家庭教育と平行 して，多くの小胃と交わらせるために普通幼稚園や万う 脬校奻稚部の参加見学をすすめた。この方法はその後に 受ける教育にも好結果をむたらした。㯖骂の訓練は家庭 で行つたものも効果的であつたが，それ以上に好結果を 得たのはダループ指導であつた. 別表に見られる如く， 㮦力障害の有無昫拘らず，言語遅滞のためにろら教育を 受ける例が多いのは注目すべきである，Wilbur (1867) はすでに聴力障害がなくろう学校に在籍する子供を報告 し，誤つた処置がとられていたことを指摘している，著 者も同じような例を経験した。万方教育を受けたために 言語環境が複雑になり遅膟をいらそう著じるしくしたと 思われるものがある。

\section{おわりに}

言語発達遅演児 466 例の臨床的钼察結果を報告した。 定例の検討は䛦断方法，言語能力の評価，原因の追及， 迈置の適正などを中心标こなつた。結果は次のように まとめられる。

1. 患者の年令は 4 才未満が大多数を占め，性別では 男児が多からた。

2. 日常音に対する患照の反応，言語能力についての 家族の評価は信頼性が低い。

3. 診断は家族の訴兄や観祭を参考比，可能な限りに 字観的な方法ですすめるのが望ましい。

4. 患者の会話能力を評価することにより逑滞の程 贸，種類，原因を推察することができる．

5. 聴哑の原因として, 娃娠や分婏の異常による脳障 曷と育児環境の不良が注目された。

6. 精神薄弱では素質の遗伝と脳障害をきたす疾患と つ関係が認められた。

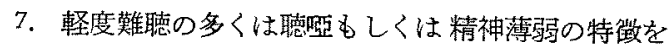
ラして括り，純粋㳗度難聴のみのものはすくない，又 与徵的な原因むつか及得なかつた。

8. 中等度以上の難恥では遗伝素質，娃娠分婏時の障

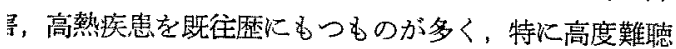
タにストレプトマイシンの影響と思われるるのが多くみ :められた。

9. 治療は早期家庭教育が効果的であつた。すべての 例について音や言語に対する関心，與味をもたせるよ 、家族を指尊する方法をとつた。

10. 万弓教育の適応については慎重な考慮が必要で ,る.

\section{參考文献}

1) Arnold, G.E.: The genetive background of developmental language disorders Folia Phonia.,1961, 13, 246. 2) Banss, T.E.: Evaluating children with language delay J.S.H.D., 1961, 26, 6 18, 3) Beckey, R.I.: Speech comes to a five year old boy J.S.H.D., 1946, 11, 197 203. 4) Beckey, R.E.: A study of certain factors related to retardation of speech J.S.H.D., 1942, 7, 223 249. 5) Bender J.F.: A case of delayed speech J.S.H.D., 1940, 5, 4. 6) Berry, M.F. \& Eisenson, J.: Speech disorders: Principles and Practices of therapy, New York: Appleton. 1942. 7) Bishop, A. and Corcoran, M.: A program for the speech inhibited child J.S.H.D., 1847, 12, 373. 8) Blackman, R.S.: Case study of delayed language J.S.H.D., 1959, 22, 381. 9) Coen, R.: Die Hörstummheit, Winner Klinik 18, 87, 7, 8, Ohr. Heilk., 1900, 36, 304. 10) Gens,G. and Bibey, M.L.: Congenital aphasia J.S.H.D., 1952, 17, 32. 11) Goldenberg, S.: An exploratory study of some aspects of idiopathic language retardation J.S.H.D., 1950, 15, 221 , 12) Goldstein, R., Landav, W.M., Kleffner, F.R.: Neurologic observation on a popuration of deaf and aphasic children Annals. O.R.L., 1958. 13) Goldstein, R., Landav, W.M., Kleffner, F.R.: Neurological assessment of some deaf and aphasic children Annals. O.R.L., 1958, 67, 468 479. 14) Green, M.C.L.: Diagnosis and treatment of late speech and language develop. ment in children Folia Phonia., 1960, 12, 101 107. 15) Guttmann, E.: Aphasia in children Brain, 1942, 65, 205 219. 16) Hannigan, H.:

Language and behavior problems of the aphasic children J.S.H.D., 1956, 21, 413 . 17) Kastein, S.: Language development among servivors of premature birth Arch. O.L., 1959, 69, 131. 18) Gewel, $F$. Speech language and hearing disorders in encepharopathy Folia Phonia., 1960, 12, 282. Karrin, I. W. and Strazulla, M.: Speech and language problems of mentally deficient children J.S.H.D., 1952, 17, 286 20) Kinney, C.E.: Loss of speech due to meningitis deafness Arch. O.L., $1948,47,303 \sim 309$.

21) Kinney, C.E.: The pa 
thology of hereditary defaness Annal. O.R. L., 1960, 59, 1117 1122. 22) Klotz, R.E.: Psychogenic hearing loss in children Annal. O.R.L., 1960, 69, 199. 23) Landev, W.M., and Kleffner, F.R.; Syndrome of acquired aphasia with convulsive disorders in children Neurology 1957, 7, 523 530. 24) Marcus, R.E.: Hearing and speech problems in children Arch. O.L., 1951, 53, 134 146. 25) Mason, M.K.: Learning to speak after six and onehalf years of silence J.S.H.D., 1942, 9, 295.

Myklebust, H.R.: Babbling and Echolalia in language development J.S.H.D., 1957, 22, 356 360. 27) Morley, M.E.: The development and disorders of speech in childhood E. \& S. Livingstone L.T.D. : 1957. 28) Nance, L.S.: Differential diagnosis of aphasia in children J.S.H.D., 1946, 11, 219 223.

29) Peacher, W.G.: Neurogical factors in the etiology of delayed speech J.S.H.D., 1949, 14, 147 161. 30) Sugar, O.: Congenital aphasia an anatomical and physiological approach J.S.H.D., 1952, 17, 301. 31) Travis, L.E.: Speech pathology New York: Appleton, 1931. 32) Werner, L.S.: Treatment of a child with delayed language J.S.H.D., 1945, 10, 329 334. 33) Worster, D.C. and Allen, I.M.: Congenital auditory imperception J. Neurology and psychopathology, 1929, 9, 193. Wolferman, A.: Congenital auditory aphasia Arch. O.L., 1955, 62, 509. 35) Worster, D.C.: Failure in normal lanuage development Folia Phonia. 1963. Basal 5.36) 小野中平：心身障害児に和ける始語期，

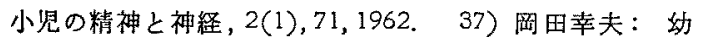
児の言語発请障害，精神神経学雑誌，63(11)，1125, 1961. 38）岡田幸夫：幼児の言語発羊障害（鑑別診断），児童 精神医学とその近接領域，2(1)，112，1961。39）絹谷

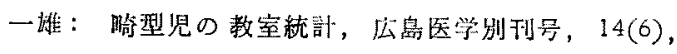
917，1961. 新生児略型に関する本邦文献展望とくに統 棓的観察について，公島医学别刊号，14(6)，754，1961. 40）河村正三, 他：奻児の言語発達について, 耳舜唸 科，35(8)，603，1963，41）鉿木昌樹，他：言語燚

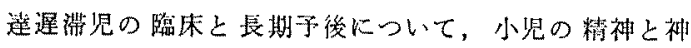
経，2(1)，38，1962。42）昭和34年度人口動態統計表， 厚生省.43) 高尾健阙：小児の神経精神医学，南山 堂.44）田中博美，他：当科外来を訪れた言語障害 児について，小胃の精神と神経，2(1)，26，1962，45) 竹本浄治: 先天性異常の臨床調查, 広島産㷌人科医会 会誌，1(1)，91，1962.46）武田栄文：国立吴病院に 扣计る先天性舆常の臨床調查，広岛源婦人科医会会誌， 1(1)，96，1962４47）田淵炤：先天性鼠常の成因（殊 に母体環境関与当研究，広島医学别刊号，14(6)，767， 1961. 48) 津守真: 乳巟精神発達診断法, 大日本因 書, 1961. 49) 西村秀雄: 先天性簧常の素因的要約, 産婦人科，82(12)，1643，1961。50) 莲池与志子：未

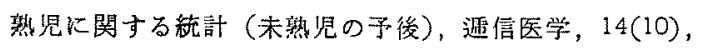
871，1961.51) 平井信和：先天性哄常の臨床調查, 公帛産婦人医科会会誌，1(1)，100，1962，52）松山信 夫: Hörstumntheit の症例，耳鼠咽喉科，29(7)，563， 1957.53) 矢田部達郎：坚童の言語, 㧱元社. 54) 山下俊郎：幼児心理学, 朝倉書房。

稳を釉るにのぞみ終始御指導と御校閲を睗つ た切替一郎教授並びに御助言をいただいた順天 堂大学河村正三助教授に梁く感謝する。

またつ机に御協力をいただいた東大分院神経 科上出弘之博士, 東大小児科丸山博博士, 東大 耳率科教室の諎先生に謝意を表する。

(原稆到着 $=$ 情和 39.1 .14 日) 